\begin{tabular}{l}
\hline OPEN O ACCESS Freely available online \\
http://www.banglajol.info/index.php/BJID/index \\
Original Article \\
Bangladesh Journal of Infectious Diseases \\
June 2015, Volume 2, Number 1 \\
ISSN (online) 2411-670X \\
ISSN (Print) 2411-4820
\end{tabular}

\title{
Knowledge and Practice Regarding HIV among Urban-Rural Men in Bangladesh: A cross sectional study
}

\author{
Rezwana Sultana ${ }^{1}$, Akkur Chandra Das ${ }^{1}$ \\ ${ }^{1}$ Department of Population Sciences, University of Dhaka, Dhaka-1000, Bangladesh
}

[Received: 1 January 2014; Accepted: 15 December 2014; Published: 1June 2015]

\begin{abstract}
Background: Human immunodeficiency virus (HIV) is one of the very much concerning issues and nearly 30 million people have died because of HIV related causes, which are found mostly low and lower income countries of the world. Objective: The objective of this study was to evaluate knowledge and practice to reduce risk factors of getting HIV among urban and rural men in Bangladesh with the comparative analysis among them. Methodology: This is a cross sectional study among 3997 men (urban=1437 and rural=2560). Frequency and percentage on knowledge and practice to reduce risk factors of getting HIV were counted to describe and also urban-rural significance levels of knowledge and practice issues regarding HIV were tested. Result: Knowledge and practice regarding HIV among urban-rural men were comparatively different where $93.7 \%$ urban and $81.9 \%$ rural men heard about HIV; $88.3 \%$ urban and $74.8 \%$ rural men thought that HIV can get by using unsterilized needle or syringe; $90.3 \%$ urban and $75.6 \%$ rural men thought that unsafe blood transfusions resulted HIV; $78.3 \%$ urban and $62.2 \%$ rural men use condom always during sex; and these urban-rural knowledge and practice related differences are statistically significant at $\mathrm{P}<.000$. Conclusion: In Bangladesh, there weren't massive differences between urban and rural men's knowledge and practice reducing risk factors of getting HIV; but urban men have comparatively more knowledge and practice levels than those of rural men have because of having urban men's higher level of socio-demographic and economic status. [Bangladesh J Infect Dis 2015;2(1):3-8]

Keywords: human immunodeficiency virus; acquired immune deficiency syndrome; sexually transmitted infection; injection drug user; urban-rural Bangladeshi woman

[How to Cite this article: Sultana R, Das AC. Knowledge and practice regarding HIV among urban- rural men in Bangladesh: A cross sectional study. Bangladesh J Infect Dis 2015;2(1):3-8]

Corresponding author: Akkur Chandra Das, Department of Population Sciences, University of Dhaka, Dhaka-1000, Bangladesh; Email: akkurdas@gmail.com; Cell no.: +8801711115858

Conflict of Interest: Authors have declared no conflict of interest.

Contributions to authors: RS has contributed in protocol preparation to manuscript writing as well as the research work and ACD analyzed the data; furthermore, he has prepared and revised the manuscript.
\end{abstract}




\section{Introduction}

Human immunodeficiency virus (HIV) causes acquired immune deficiency syndrome (AIDS), which is mainly transmitted because of unsafe sexual intercourse, intravenous injections with contaminated needles, unscreened or contaminated blood transfusions, and transmission from an infected mother to a child during pregnancy, delivery, or breastfeeding and has become one of the world's most serious healthcare challenges where approximately 34 million people currently live with HIV, and nearly 30 million people have died of AIDS related causes since the beginning of the epidemic though almost all those people living with HIV reside in low and lower income countries of the world ${ }^{1}$. Among the developing countries in Asia, Bangladesh still has a low level HIV epidemic status, where the adult prevalence of HIV infection is estimated to be below $0.1 \%{ }^{2}$. In Bangladesh, the HIV infection rates are still low $^{3}$ but are now rising day by day in some populations because of some global development indicators such as income levels, literacy, status of women, nutritional levels and health related indicators such as infant or maternal mortality ${ }^{4}$. On the other hand, poverty, stigma, lack of access to care, low education, gender inequality, and lack of a facilitative legal environment are various dimensions of exclusion of such high-risk groups that lead to risky sexual behaviours among them. Although Bangladesh has so far maintained a low prevalence of HIV, their high prevalence of risky behaviors might counterbalance the prevention efforts that have been put in place ${ }^{6}$ and it is a low-epidemic country where HIV/AIDS is believed to be highly sensitive in terms of the socio cultural and religious contexts ${ }^{7}$.

Knowledge about HIV transmission is vitally important in the prevention of an HIV epidemic. Correct knowledge about HIV transmission increases safer sexual behavior and is considered an important step toward behavioral change ${ }^{8}$. At the same time, misconceptions can prevent individuals from safer sexual behavior and taking appropriate action against HIV acquisition and transmission. HIV and AIDS continue to be associated with many misconceptions and misinformed opinions where knowledge is an important prerequisite for preventing HIV transmission and for behavioral change ${ }^{9}$. Consequently, it is important to understand how accurate and inaccurate knowledge can contribute to HIV transmission ${ }^{10}$. Although many people have heard about HIV, their knowledge is limited with regard to how it is transmitted and how they can protect themselves. Many esteemed studies have been conducted in both developing and developed regions to identify the relations between misconceptions and socio-demographic risk factors among women or the general population ${ }^{8,10-17}$. On the other hand, HIV epidemic continues to be associated with misconceptions and misinformed opinions, which increase the risk of HIV transmission $^{18}$. Not surprisingly, awareness of AIDS was found to be positively related to literacy level ${ }^{19}$. This was also found to be the case in a study of 3687 women and 2272 men in rural Bangladesh where literacy was the most significant predictor of AIDS awareness ${ }^{20}$. Limited knowledge about HIV may also contribute to the spread of the HIV virus in Bangladesh because of having very low levels of awareness of HIV and even lower levels of knowledge of routes of transmission but by general population studies have found levels of awareness ranging from $19 \%{ }^{21}$ to $40 \%{ }^{19}$. However, Bangladesh is still at the beginning of an evolving epidemic of HIV associated disease and opportunistic infections $^{22}$. HIV affects economic growths by reducing the human capitals ${ }^{23}$ so that useful and fruitful media campaigns to educate the people regarding the health consequences of STDs including HIV and integrated approach is strongly suggested for disseminating knowledge and awareness to control the spread of HIV among people in Bangladesh $^{24}$ with the appropriate treatment practices for sexually transmitted infections need to be encouraged and condom use promoted particularly in the context of casual sexual relations ${ }^{25}$ and it is noted that consistent condom use is a major safeguard against sexually transmitted diseases including HIV ${ }^{26}$ which can be reduced by providing proper information about the knowledge and practice regarding risk factors of getting $\mathrm{HIV}^{27}$. Therefore, the objective of this study was to evaluate knowledge and practice of reducing risk factors of getting HIV among urban and rural men in Bangladesh with the comparative analysis among them.

\section{Methodology}

The cross sectional study was conducted by using data from Bangladesh Demographic and Health Survey (BDHS) 2011. As part of global Demographic and Health Survey (DHS) program, the BDHS 2011 is nationally representative household based survey conducted to obtain information on health and demography, and also on HIV/AIDS where all of the data were collected from seven divisions in Bangladesh. This is a cross sectional study among 3997 men where there were 1437 urban and 2560 rural men. Then first the data 
were analyzed in frequency and percentage to describe the respondents' knowledge and practice to reduce risk of getting HIV. Second, Pearson ChiSquare test was applied for testing significance level among rural and urban respondents' knowledge and practice of reducing risk factors of getting HIV related issues. All the analysis was done by using Statistical Package for the Social Sciences (SPSS) version 16.

\section{Result}

A total number of study samples were 3997 men and among them there were $36 \%$ men from urban and $64 \%$ men from rural area. Age of the respondents was below 25 years 6\%, 25-39 years respondents were $48 \%$ and 40-54 years respondents were $46 \%$ of this study. Among the total respondents 3966(99.2\%) were married and left 31 $(0.8 \%)$ respondents were windowed/ divorced/ separated men. The respondents' education levels were no education $25.8 \%$, primary $33.5 \%$ and secondary or higher education receivers were $40.6 \%$. There were $36.7 \%$ poor respondents, only $19.2 \%$ were middle in wealth index and $44.1 \%$ respondents were rich. There were $87.4 \%$ Muslim, $12 \%$ were Hindu and $0.6 \%$ were other religion followers (Table 1).

Table 1 Sample Characteristics $(n=3997)$

\begin{tabular}{lcc}
\hline Variables & Frequency & Percentage \\
\hline $\begin{array}{l}\text { Type of Residence } \\
\text { Place }\end{array}$ & \\
Urban & 1437 & 36.0 \\
Rural & 2560 & 64.0 \\
Age of the respondents & & \\
$<25$ & 240 & 6.0 \\
$25-39$ & 1920 & 48.0 \\
$40-54$ & 1837 & 46.0 \\
Marital Status & & \\
Married & 3966 & 99.2 \\
Widowed/Divorced/ & 31 & 0.8 \\
Separated & & \\
Education & & \\
No education & 1031 & 25.8 \\
Primary & 1340 & 33.5 \\
Secondary/ Higher & 2626 & 40.6 \\
Wealth Index & & \\
Poor & 1464 & 36.7 \\
Middle & 769 & 19.2 \\
Rich & 1764 & 44.1 \\
Islam & 3496 & 87.4 \\
Hinduism & 478 & 12.0 \\
Other & 23 & 0.6 \\
\hline Religion & & \\
\hline
\end{tabular}

Table 2 Knowledge about HIV $(n=3997)$

\begin{tabular}{|c|c|c|}
\hline Variables & Frequency & Percentage \\
\hline \multicolumn{3}{|l|}{$\begin{array}{l}\text { Ever heard about } \\
\text { HIV }\end{array}$} \\
\hline Yes & 3436 & 86.0 \\
\hline No & 561 & 14.0 \\
\hline \multicolumn{3}{|c|}{$\begin{array}{l}\text { Can get HIV from } \\
\text { mosquitoes bites }\end{array}$} \\
\hline Yes & 1441 & 36.1 \\
\hline No & 2556 & 63.9 \\
\hline \multicolumn{3}{|c|}{$\begin{array}{l}\text { Can get HIV by } \\
\text { sharing food with } \\
\text { person who has HIV }\end{array}$} \\
\hline Yes & 1468 & 36.7 \\
\hline No & 2529 & 63.3 \\
\hline \multicolumn{3}{|l|}{$\begin{array}{l}\text { A healthy looking } \\
\text { person can have }\end{array}$} \\
\hline HIV & 2843 & 71.1 \\
\hline $\begin{array}{l}\text { Yes } \\
\text { No }\end{array}$ & 1154 & 28.9 \\
\hline \multicolumn{3}{|c|}{$\begin{array}{l}\text { Can get HIV by } \\
\text { witchcraft or } \\
\text { supernatural means }\end{array}$} \\
\hline Yes & 341 & 8.5 \\
\hline No & 3656 & 91.5 \\
\hline \multicolumn{3}{|l|}{$\begin{array}{l}\text { Can get HIV by } \\
\text { using unsterilized } \\
\text { needle or syringe }\end{array}$} \\
\hline Yes & 3185 & 79.7 \\
\hline No & 812 & 20.3 \\
\hline \multicolumn{3}{|c|}{$\begin{array}{l}\text { Can get AIDS virus } \\
\text { through unsafe } \\
\text { blood transfusions }\end{array}$} \\
\hline Yes & 3232 & 80.9 \\
\hline No & 765 & 19.1 \\
\hline
\end{tabular}

Table 2 presents the information about the knowledge of HIV where $86 \%$ men heard about HIV but $14 \%$ men did not hear about HIV; $36.1 \%$ men think that HIV can get from mosquitoes bites and do not think $63.9 \%$. There were $36.7 \%$ men who think that HIV can get by sharing food with the person who has HIV but $63.3 \%$ men do not think it; $71.1 \%$ men think that a healthy looking person can have HIV but $28.9 \%$ men don't. On the other hand, $8.5 \%$ men think that HIV can get by witchcraft or supernatural means but majority $91.5 \%$ men do not think that HIV can get by supernatural means. However, HIV can get by using unsterilized needle or syringe $79.7 \%$ respondents think but $20.3 \%$ do not think; $80.9 \%$ men think HIV can get through unsafe blood transfusions and $19.1 \%$ think negative of this statement.

Table 3 shows the practice information on reducing risk factors of getting HIV where always use 
condom during sex $68 \%$ and do not use $32 \%$ of the total respondents of this study. On the contrary, there were $67.7 \%$ of the respondents who have only 1 sex partner but $32.4 \%$ men of this study found that they have more than 1 sex partner.

Table 3: Practice factors to reduce risk of getting HIV (n=3997)

\begin{tabular}{lcc}
\hline Variables & Frequency & Percentage \\
\hline $\begin{array}{l}\text { Always use condom } \\
\text { during sex }\end{array}$ & & \\
Yes & 2718 & 68.0 \\
No & 1279 & 32.0 \\
Have 1 sex partner only, & & \\
who has no other partner & & \\
Yes & 2700 & 67.7 \\
No & 1297 & 32.4 \\
\hline
\end{tabular}

Table 4 contains the information of the men's knowledge about HIV and type of residence place where among urban respondents $93.7 \%$ heard about HIV and did not hear $6.7 \%$ but among rural $81.9 \%$ respondents heard about HIV and did not hear $18.4 \%$ about HIV, which is significantly associated at $\mathrm{P}<.000$. Urban $35.4 \%$ men think that HIV can get from mosquitoes bites and do not think $64.6 \%$ but rural men think $36.4 \%$ HIV can get from mosquitoes bites. HIV Can get by sharing food with the person who has HIV that was thought $33.8 \%$ men among urban respondents but rural thought $38.4 \%$, a healthy looking person can have HIV thought by urban $78.1 \%$ and rural men thought $67.2 \%$; HIV also can get by witchcraft or supernatural means what was thought by urban $7.4 \%$ and $9.1 \%$ rural men. On the other hand, HIV can get by using unsterilized needle or syringe thought urban $88.3 \%$ but $74.8 \%$ rural men; AIDS virus can get unsafe blood transfusions thought by urban $90.3 \%$ but $75.6 \%$ rural men of this study.

Table 5 presents the cross tabulation between practice to reduce risk factors of getting HIV and type of residence place where $78.3 \%$ urban and $62.2 \%$ rural men use condom always during sex but don't use always condom urban $21.7 \%$ and $37.8 \%$ rural men during sex of this study. On the other hand, urban $73.7 \%$ but $64.1 \%$ rural men of this study have 1 sex partner only and they have no other sex partner.

\section{Discussion}

Demographic and socioeconomic factors are mostly related with the health of male and female but the urban-rural factor was more important than the socioeconomic factor where health promotion and education programs can play an important role in improving the sexual and reproductive health knowledge situation ${ }^{28}$. Urban people know much about HIV than rural people found in this study where men's education, wife's education, family income, and wealth index are related.

Table 4: Knowledge about HIV and Residence Place $(n=3997)$

\begin{tabular}{|c|c|c|c|}
\hline \multirow[t]{2}{*}{ Variables } & \multicolumn{2}{|c|}{ Residence Place } & \multirow[t]{2}{*}{$\mathrm{P}$ value } \\
\hline & $\begin{array}{c}\text { Urban } \\
(n=1437)\end{array}$ & $\begin{array}{c}\text { Rural } \\
(n=2560)\end{array}$ & \\
\hline \multicolumn{4}{|c|}{$\begin{array}{l}\text { Ever heard about } \\
\text { HIV }\end{array}$} \\
\hline Yes & $1347(93.7 \%)$ & $2089(81.9 \%)$ & 0.0001 \\
\hline No & $90(6.7 \%)$ & $471(18.4 \%)$ & \\
\hline \multicolumn{4}{|c|}{$\begin{array}{l}\text { Can get HIV } \\
\text { from mosquitoes } \\
\text { bites }\end{array}$} \\
\hline Yes & & & \\
\hline No & $\begin{array}{l}509(35.4 \%) \\
928(64.6 \%)\end{array}$ & $\begin{array}{c}932(36.4 \%) \\
1628(63.6 \%)\end{array}$ & 0.278 \\
\hline \multicolumn{4}{|c|}{$\begin{array}{l}\text { Can get HIV by } \\
\text { sharing food } \\
\text { with person who } \\
\text { has HIV } \\
\text { Yes }\end{array}$} \\
\hline No & $\begin{array}{l}485(33.8 \%) \\
952(66.2 \%)\end{array}$ & $\begin{array}{c}983(38.4 \%) \\
1577(61.6 \%)\end{array}$ & 0.002 \\
\hline \multicolumn{4}{|c|}{$\begin{array}{l}\text { A healthy } \\
\text { looking person } \\
\text { can have HIV } \\
\text { Yes }\end{array}$} \\
\hline No & $\begin{array}{c}1123(78.1 \%) \\
314(21.9 \%)\end{array}$ & $\begin{array}{c}1720(67.2 \%) \\
840(32.8 \%)\end{array}$ & 0.0001 \\
\hline \multicolumn{4}{|c|}{$\begin{array}{l}\text { Can get HIV by } \\
\text { witchcraft/ } \\
\text { supernatural } \\
\text { means }\end{array}$} \\
\hline Yes & $107(7.4 \%)$ & $234(9.1 \%)$ & 0.037 \\
\hline No & $1330(92.6 \%)$ & $2326(90.9 \%)$ & \\
\hline \multicolumn{4}{|c|}{$\begin{array}{l}\text { Can get HIV by } \\
\text { using } \\
\text { unsterilized } \\
\text { needle or } \\
\text { syringe }\end{array}$} \\
\hline $\begin{array}{l}\text { Yes } \\
\text { No }\end{array}$ & $\begin{array}{c}1269(88.3 \%) \\
168(11.7 \%)\end{array}$ & $\begin{array}{c}1916(74.8) \\
644(25.2)\end{array}$ & 0.0001 \\
\hline \multicolumn{4}{|c|}{$\begin{array}{l}\text { Can get AIDS } \\
\text { virus through } \\
\text { unsafe blood } \\
\text { transfusions }\end{array}$} \\
\hline Yes & $1297(90.3 \%)$ & $1935(75.6 \%)$ & 0.0001 \\
\hline No & $140(9.7 \%)$ & $625(24.4 \%)$ & \\
\hline
\end{tabular}

However, knowledge about HIV transmission and ways to prevent it are of little use if women feel powerless to negotiate safer sex practices with their 
husbands. In this regard, an educated husband could play an effective role ${ }^{29}$.

Table 5 Practice factors to reduce risk of getting HIV and Residence Place $(\mathbf{n}=3997)$

\begin{tabular}{lccc}
\hline \multirow{2}{*}{ Variables } & \multicolumn{2}{c}{ Residence Place } & \multirow{2}{*}{ P value } \\
\cline { 2 - 3 } & $\begin{array}{c}\text { Urban } \\
(\mathrm{n}=1437)\end{array}$ & $\begin{array}{c}\text { Rural } \\
(\mathrm{n}=2560)\end{array}$ & \\
\hline Always use & & & \\
condom & & & \\
during sex & & & \\
$\quad$ Yes & $1125(78.3 \%)$ & $1593(62.2)$ & 0.0001 \\
$\quad$ No & $312(21.7 \%)$ & $967(37.8 \%)$ & \\
Have 1 sex & & & \\
partner only, & & & \\
who has no & & & \\
other partner & & & \\
Yes & $1059(73.7 \%)$ & $1641(64.1 \%)$ & 0.0001 \\
$\quad$ No & $378(26.3 \%)$ & $919(35.9 \%)$ & \\
\hline
\end{tabular}

In this study, it is noted that rural men are not aware about HIV than urban and also they don't have much knowledge reducing risk factors of getting HIV. By another study found that female injection drug users (IDU) in Bangladesh are at risk of a major HIV epidemic from both injection sharing and sexual risk behavior and sex worker IDU appear especially vulnerable ${ }^{30}$. It is also noted that eightynine percent of the respondents responded that a condom is a rubber material while $11 \%$ considered it a birth control material ${ }^{30}$ and women who inject drugs are among the most vulnerable to HIV through both unsafe injections and unprotected $\operatorname{sex}^{31-32}$. On the other hand, all over the world, HIV is very much concerning one of the issues but then rural men have lacking about the knowledge and prevention of HIV. After all, the study found that Bangladesh has not been facing a huge number of HIV contained people but there are many possibilities to be increased the number of HIV survivors if the proper knowledge and practice of reducing risk factors don't provide immediately.

\section{Conclusion}

The overall study revealed that there weren't massive differences between urban and rural men's knowledge and practice reducing risk factors of getting HIV in Bangladesh; but urban men have comparatively more knowledge and practice levels than those of rural men have because of urban men having higher level of socio-demographic and economic status. In this study, there was very little information found on practice of reducing risk factors of getting HIV so that highlighting practice issues another well-designed research recommended to indentify proper and do effective evaluation. On the contrary, there were many sensitive personal/ family issues and the respondents might not have disclosed intentionally due to cultural and religious beliefs. This might affect outcome of the study leading to some bias in the result.

\section{Acknowledgement}

We thank the Measure DHS for making BDHS 2011 data available to us for analysis. We also like to thank all men who participated in BDHS 2011.

\section{References}

1. Joint United Nations Programme on HIV/AIDS (UNAIDS). World AIDS Day Report 2011. UNAIDS, Geneva; 2011

2. UNAIDS: Report on global AIDS epidemic: 2008. UNAIDS;2008

3. Govt. of Bangladesh: National HIV Serological Surveillance, $6^{\text {th }}$ Round Technical Report, 2004-2005 Bangladesh. Dhaka, National AIDS/STD Programme, Directorate General of Health Services, Ministry of Health and Family Welfare, Govt. of Bangladesh.; 2005

4. Cleland J, Phillips J, Amin S, Kamal GM. The determinants of reproductive change in Bangladesh. Washington, DC: World Bank, 1994

5. Chan PA, Khan OA. Risk factors for HIV infection in males who have sex with males (MSM) in Bangladesh. BMC Public Health 2007;7:153

6. Islam MM, Conigrave KM. HIV and sexual risk behaviors among recognized high-risk groups in Bangladesh: need for a comprehensive prevention program. Int J Infect Dis 2008;12(4):363-70

7. Sarma H, Oliveras E. Implementing HIV/AIDS education: impact of teachers' training on HIV/AIDS education in Bangladesh. J Health Popul Nutri 2013;31(1):20-7

8. Tenkorang EY. Myths and misconceptions about HIV transmission in Ghana: what are the drivers? Cult Health Sex 2013;15:296-310

9. Joint United Nations Programme on HIV/AIDS (UNAIDS). National AIDS programs: a guide to monitoring and evaluation. Geneva; 2000

10. Letamo G. Misconceptions about HIV prevention and transmission in Botswana. Afr J AIDS Res 2007;6:193-8

11. Rahman MM, Kabir M, Shahidullah M. Adolescent knowledge and awareness about AIDS/HIV and factors affecting them in Bangladesh. J Ayub Med Coll Abbottabad 2009;21:36

12. Mondal NI, Islam R, Rahman O, Rahman, S, Hoque, N. Determinants of HIV/AIDS awareness among garments workers in Dhaka city, Bangladesh. World J AIDS 2012;2:312-8

13. Rauf W, Hitchcock S, Rauf A, Becker, PJ. Knowledge of and misconceptions about the spread and prevention of HIV infection among older urban women attending the Tshwane District Hospital, South Africa. SA Fam Pract 2010;52:142-8

14. Ochako R, Ulwodi D, Njagi P, Kimetu, S, Onyango, A. Trends and determinants of Comprehensive HIV and AIDS knowledge among urban young women in Kenya. AIDS Res Ther 2011;8:11

15. Mondal NI, Rahman M, Rahman O, Akter, N. Level of awareness about HIV/AIDS among ever married women in Bangladesh. Food Public Health 2012;2:73-8 
16. Mondal NI, Khan AR, Islam R, Mamun, AA. Commercial sex workers in brothels are hallmark of HIV epidemic in Bangladesh. Pakistan J Soc Sci 2005;3(9):1152-8

17. Fraim NL. Knowledge levels and misconceptions about HIV/AIDS: what do university students in Turkey really know? Int J Humanit Soc Sci 2012;2:50-8

18. Mondal MN, Hoque N, Chowdhury MR, Hossain MS.Factors associated with misconceptions about HIV transmission among ever-married women in Bangladesh. Jpn J Infect Dis 2015;68(1):13-9

19. National AIDS Committee. KABP Survey in Relation to AIDS in Bangladesh. Dhaka: NAC; 1990

20. Fulton EL, Kama N, Ahmed SM, Khan MI. Determinants of AIDS awareness and knowledge among rural men and women in Bangladesh. ASCON VI ${ }^{\text {th }}$ Conference; Dhaka, Bangladesh: International Centre for Diarrhoeal Disease Research, Bangladesh. March 1997; Special Publication No. 57

21. Hanifi MA, Hossain M, Aziz A, Bhuiya A. Impact of AIDS awareness activities in a remote rural area of Bangladesh. ASCON $\mathrm{VI}^{\text {th }}$ Conference; Dhaka, Bangladesh: International Centre for Diarrhoeal Disease Research, Bangladesh. March 1997; Special Publication No. 57

22. Matin N, Shahrin L, Pervez MM, Banu S, Ahmed D, Khatun M, et al. Clinical profile of HIV/AIDS-infected patients admitted to a new specialist unit in Dhaka, Bangladesh a low prevalence country for HIV. J Health Popul Nutri 2011;29(1):14-9

23. Roy S. The effects of HIV/AIDS on economic growth and human capitals: a panel study evidence from Asian countries. AIDS Care 2014;26(12):1568-75
24. Rahman MM, Kabir M, Shahidullah M. Knowledge of AIDS and condom as a preventive measure against AIDS among married males and factors influencing it in Bangladesh. Kathmandu Univ Med J 2007;5(3):364-70

25. Gibney L, Saquib N, Metzger J. Behavioral risk factors for STD/HIV transmission in Bangladesh's trucking industry. Soc Sci Med 2003;56(7):1411-24

26. Eva NA, Munakata T, Onuoha FN. Demographic correlates of constant condom use among sex workers in Tangail, Dhaka, Bangladesh. Adolescence 2007 Winter; 42(168):795-804

27. Sayem A. An assessment of risk behaviours to HIV/AIDS vulnerability among young female garment workers in Bangladesh. Int J STD AIDS 2010;21(2):133-7

28. Gani MS, Chowdhury AM, Nyström L. Urban-rural and socioeconomic variations in the knowledge of STIs and AIDS among Bangladeshi adolescents. Asia Pac J Public Health 2014;26(2):182-95

29. Azim T, Chowdhury EI, Reza M, Ahmed M, Uddin MT, Khan R, et al. Vulnerability to HIV infection among sex worker and non-sex worker female injecting drug users in Dhaka, Bangladesh: evidence from the baseline survey of a cohort study. Harm Reduc J 2006;3:33

30. Rahman M, Wali-ulIslam M, Fukui T. Knowledge and practices about HIV/AIDS among the commercial sex workers in Bangladesh. J epid / Japan Epid Association 1998;8(3):181-3

31. Mondal MN, Hoque N, Chowdhury MR, Hossain MS. Factors associated with misconceptions about HIV transmission among ever-married women in Bangladesh. Japanese $\mathrm{J}$ infect dis 2015;68(1):13-9

32. Azim T, Bontell I, Strathdee SA. Women, drugs and HIV. Int J Drug Policy 2015;26 Suppl 1:S16-21 